\title{
EFFECTS OF BIOFERTILIZERS COMBINED WITH DIFFERENT SOIL AMENDMENTS ON POTTED RICE PLANTS
}

\author{
Arshad Javaid ${ }^{1 *}$
}

\begin{abstract}
This pot study investigated the effect of the combined application of two commercial biofertilizers viz. Biopower and EM (Effective Microorganisms) on rice (Oryza sativa L.) growth and yield in soils amended with farmyard manure, green manure, and NPK fertilizers. Biopower is a product of the Nuclear Institute for Biotechnology and Genetic Engineering (NIBGE), Pakistan, which contains species of associative and endophytic diazotrophs. EM (effective microorganisms), a product developed by Japanese scientists, consists of co-existing beneficial microorganisms, mainly species of photosynthetic and lactic acid bacteria, as well as yeast. Applying Biopower adversely affected plant growth and yield in NPK fertilizer amendment. Conversely, this biofertilizer markedly enhanced plant growth and yield in green manure amended soil while its effect was not significant in farmyard manure amendment. In green manure amendment, applying EM enhanced grain yield by $46 \%$. Co-inoculation of Biopower and EM evidently improved root and shoot growth in farmyard manure amended soil. This study concludes that the two biofertilizers clearly enhanced shoot biomass and grain yield in green manure amended soils.
\end{abstract}

Key words: Associated $\mathrm{N}_{2}$-fixers, Biopower, effective microorganisms, rice, soil amendments.

\section{INTRODUCTION}

Rice (Oryza sativa L.) is probably the most important cereal in the world and serves as food for about $50 \%$ of the world's population (Ladha et al., 1997). This crop requires about 10 million tons of $\mathrm{N}$ fertilizers every year worldwide (IRRI, 1996). Rice is usually grown in $\mathrm{N}$-deficient soils, and this element must be supplied to the field by commercially available $\mathrm{N}$ fertilizers. However, a substantial amount of urea- $\mathrm{N}$ or $\mathrm{NO}_{3}-\mathrm{N}$ applied as fertilizers is lost through different mechanisms, thus causing environmental pollution problems. Use of biological $\mathrm{N}_{2}$-fixation technology can decrease $\mathrm{N}$ fertilizer application and reduce environmental risks (Raimam et al., 2007). This process can contribute as much as $75 \mathrm{~kg} \mathrm{~N} \mathrm{ha}^{-1}$ per crop cycle with means of 8 to $30 \mathrm{~kg} \mathrm{~N} \mathrm{ha}^{-1}$ (Irissarri and Reinhold-Hurek, 2001). These $\mathrm{N}$-fixing bacteria may be free-living or naturally associated to rice plants. Recent studies have shown that

${ }^{1}$ University of the Punjab, Institute of Plant Pathology, Quaid-eAzam Campus, Lahore, Pakistan.

*Corresponding author (arshadjpk@yahoo.com).

Received: 3 August 2010.

Accepted: 15 November 2010. several bacteria may be isolated from sterilized surface roots of flooded rice plants, suggesting endophytic colonization (Raimam et al., 2007). The most likely candidates for biological $\mathrm{N}$ fixation in rice are species of Alcaligenes, Azospirillum, Bacillus, Enterobacter, Herbaspirillum, Klebsiella, Pseudomonas, and Rhizobium (Malik et al., 1997; James et al., 1999; Yanni et al., 1997). From the soil and plant materials collected from different areas of Pakistan, scientists of the Nuclear Institute for Biotechnology and Genetic Engineering (NIBGE), Faisalabad, Pakistan have isolated a number of bacterial strains belonging to the Azospirillum, Azotobacter, Pseudomonas, and Zoogloes genera. After laboratory testing and studying field performance, efficient bacterial strains for biofertilizer production were finally selected.A suitable carrier material was selected after trying a number of local materials to ensure maximum survival of the inoculated bacteria during storage and transportation. They named this biofertilizer Biopower.

EM (effective microorganisms) technology of nature farming was introduced by Higa (1991). EM culture consists of co-existing beneficial microorganisms, mainly species of photosynthetic bacteria (Rhodopseudomonas plastris and Rhodobacter sphacrodes), lactobacilli 
(Lactobacillus plantarum, L. casei, and Streptococcus lactis), yeast (Saccharomyces spp.), and actinomycetes (Streptomyces spp.), which improve crop growth and yield by increasing photosynthesis, producing bioactive substances, such as hormones and enzymes, controlling soil diseases, and accelerating decomposition of lignin materials in the soil (Higa, 2000; Hussain et al., 2002). This technology of nature farming was introduced in Pakistan in 1990 by the Nature Farming Research Centre of the University of Agriculture, Faisalabad. Numerous field and greenhouse trials indicate the benefits of EM as a biofertilizer in crop production, as a probiotic in poultry and livestock rations, and as a starter to improve composting and recycling of municipal/industrial wastes and effluents (Hussain et al., 1999). There are controversial reports about the effect of applying EM on crop growth and yield. Many researchers have reported an increase in crop growth and yield by applying EM (Daly and Stewart, 1999; Yan and Xu, 2002; Javaid, 2006; 2009; Khaliq et al., 2006; Javaid and Mahmood, 2010). However, other researchers have revealed that the effect of EM on crop growth and yield was not usually evident or even negative, especially in the first test crop (Bajwa et al., 1999; Daiss et al., 2008; Javaid et al., 2008, Javaid and Shah, 2010).

Earlier researchers conducted studies by using either effective microorganisms or associative $\mathrm{N}_{2}$ fixing organisms. However, there are no studies on the effect of combined inoculation of these two biofertilizers on rice growth and yield. Therefore, this pot study investigated the effect of the combined application of effective microorganisms and Biopower on rice growth and yield in soil amended either with NPK fertilizers or two types of organic manures viz. farmyard and green.

\section{MATERIALS AND METHODS}

\section{Soil characteristics}

Loamy textured soil with organic matter $0.9 \%, \mathrm{pH}$ $7.8,0.045 \% \mathrm{~N}, 14 \mathrm{mg} \mathrm{kg}^{-1}$ available $\mathrm{P}$, and $210 \mathrm{mg}$ $\mathrm{kg}^{-1}$ available $\mathrm{K}$ was employed in the experiment. Micronutrients $\mathrm{Fe}, \mathrm{Cu}$, and $\mathrm{Zn}$ were $9.53,1.71$, and $4.42 \mathrm{mg} \mathrm{kg}^{-1}$ of soil, respectively. The experiment was conducted in the Botanical Garden of the University of the Punjab, Lahore $\left(31.57^{\circ} \mathrm{N}, 74.31^{\circ} \mathrm{E}\right)$, Pakistan.

\section{Soil amendments}

Earthen pots, 20-cm diameter and 30-cm depth, were filled with $5 \mathrm{~kg}$ soil. Soil was amended either with

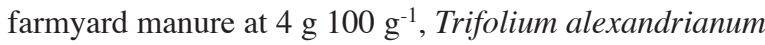

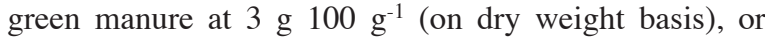
NPK fertilizers. A basal dose of $40 \mathrm{mg} \mathrm{kg}^{-1} \mathrm{~N}$ as urea (half of recommended dose), $30 \mathrm{mg} \mathrm{kg}^{-1} \mathrm{P}_{2} \mathrm{O}_{5}$ as triple superphosphate, and $20 \mathrm{mg} \mathrm{kg}^{-1} \mathrm{~K}_{2} \mathrm{O}$ as potassium sulfate was supplied to NPK treatment pot soil. NPK fertilizers were mixed $3 \mathrm{~d}$ prior to sowing. All pots were irrigated with tap water and left for $20 \mathrm{~d}$ for organic material decomposition.

\section{Treatments and experimental design}

There were four treatments, with three replicates, for each of the three soil amendment systems. These were; i) control, ii) effective microorganisms, iii) Biopower, and iv) Biopower + effective microorganisms. The experimental design was completely randomized. Pots were arranged on a bench in a wire-netting greenhouse under natural environmental conditions.

\section{Effective microorganism application}

The effective microorganism (EM) culture, commercially known as EM Bioaab, was obtained from the Nature Farming Research and Development Foundation, Faisalabad, Pakistan. EM contained high populations of lactic acid bacteria at $1 \times 10^{11} \mathrm{cfu} \mathrm{mL}^{-1}$, photosynthetic bacteria at $1 \times 10^{6} \mathrm{cfu} \mathrm{mL}^{-1}$, and $1 \times 10^{3} \mathrm{cfu} \mathrm{mL}^{-1}$ yeast suspension (Higa, 2000). Stock culture was diluted by adding tap water to prepare a $0.2 \%$ solution. The fresh solution was used immediately. The respective treatment pots with effective microorganisms applied in all three soil amendment systems were irrigated with a $0.2 \%$ diluted EM solution $15 \mathrm{~d}$ prior to sowing. Each pot received $1 \mathrm{~L}$ of diluted EM solution. These pots were further supplemented with $1 \mathrm{~L}$ of $0.2 \%$ EM solution every $2 \mathrm{wk}$ throughout the experimental period (Yadav, 2002).

\section{Biopower application}

Commercial Biopower was obtained from the Nuclear Institute for Biotechnology and Genetic Engineering, Faisalabad, Pakistan. Biopower was mixed in $100 \mathrm{~g} \mathrm{~L}^{-1}$ water. One-month-old rice plants var. Super Basmati were immersed in the Biopower solution for $1 \mathrm{~h}$ and transplanted three plants per pot. All pots were flooded with tap water. Flooded conditions were maintained throughout the experimental period, except during the last month.

\section{Harvesting}

Plants were harvested 90, 120, and $150 \mathrm{~d}$ after sowing. Shoot length was measured and number of tillers was counted for each plant. Root and shoot materials were dried at $60{ }^{\circ} \mathrm{C}$ until constant weight and then weighed. Grain yield per plant and 100-grain weight were also recorded at final harvest. 


\section{Statistical analysis}

There were three replicates for each treatment, and mean data per plant was calculated for various studied parameters. Data of various root and shoot growth, as well as yield parameters were subjected to ANOVA. This was followed by Duncan's Multiple Range Test with the SPSS and CoStat software to delineate mean differences (Steel and Torrie, 1980).

\section{RESULTS AND DISCUSSION}

\section{Effect of biofertilizers and soil amendments on plant} vegetative growth

ANOVA shows that the effect of soil amendments (A) was significant for all root and shoot growth parameters at the three growth stages (Tables 1 and 3). In general, plant growth was better in farmyard manure than in NPK fertilizers and green manure amendments (Table 2). Except in some cases, the general effect of EM and Biopower (B) was not significant for various vegetative growth parameters at different growth stages. The interactive effect of $\mathrm{A} \times \mathrm{B}$ and $\mathrm{A} \times \mathrm{EM}$ was significant for root biomass at the $90 \mathrm{~d}$ growth stage. Similarly, the effect of $\mathrm{A} \times \mathrm{EM}$ was significant for shoot length at the 120 and $150 \mathrm{~d}$ growth stages. The tripartite interactive effect of $\mathrm{A} \times \mathrm{B} \times \mathrm{EM}$ was significant for shoot length at all three growth stages, and for root biomass at 120 and $150 \mathrm{~d}$ (Tables 1 and 3).

Effect of the two biofertilizers on shoot length was not significant in all three soil amendment systems at the $90 \mathrm{~d}$ growth stage. At $120 \mathrm{~d}$, combined inoculation of the two biofertilizers markedly enhanced shoot length in NPK and green manure amended soils. Applying Biopower at the final growth stage significantly enhanced shoot length in green manure and farmyard manure amended soils. EM applied either alone or combined with Biopower did not result in a significant increase in shoot length (Table 2).

Number of tillers in different soil amendment systems varied at the first two growth stages with the effect of single as well as combined inoculation of the two biofertilizers. In general, applying biofertilizer either reduced tillering or exhibited no effect on this parameter. However, at the final growth stage, the number of tillers significantly increased with EM application, either alone or combined with Biopower, in the farmyard manure amendment (Table 2).

At different growth stages, shoot biomass either declined or remained unaffected due to separate or combined inoculation of the two biofertilizers in NPK fertilizer amended soil. In contrast, in the green manure amendment, both biofertilizers generally increased shoot biomass at all three growth stages. The effect of both biofertilizers was not appreciable at the 90 and 120 $\mathrm{d}$ growth stages in the farmyard manure amendment. However, at the $150 \mathrm{~d}$ growth stage, a marked increase in shoot biomass was recorded by both biofertilizers. The effect of combined inoculation was more evident than when they were used alone (Table 2).

Variable response of root biomass to two applied biofertilizers was recorded in different soil amendment systems. There was no definite pattern of root biomass production at different growth stages in response to either of the two biofertilizer treatments in NPK fertilizers. Both biofertilizers generally enhanced root biomass at different growth stages in the green manure amendment. In the farmyard manure amendment, after an initial decline at

Table 1. ANOVA for the effect of soil amendments, biopower, and EM application on various rice vegetative growth parameters after 90 and $120 \mathrm{~d}$ growth stages.

\begin{tabular}{|c|c|c|c|c|c|c|c|c|c|}
\hline \multirow[b]{2}{*}{ Trait } & \multirow[b]{2}{*}{ df } & \multicolumn{4}{|c|}{$90 \mathrm{~d}$ after sowing } & \multicolumn{4}{|c|}{$120 \mathrm{~d}$ after sowing } \\
\hline & & $\begin{array}{l}\text { Shoot } \\
\text { length }\end{array}$ & $\begin{array}{l}\mathbf{N}^{\circ} \text { of } \\
\text { tillers per } \\
\text { plant }\end{array}$ & $\begin{array}{c}\text { Shoot } \\
\text { biomass }\end{array}$ & $\underset{\text { biomass }}{\text { Root }}$ & $\begin{array}{l}\text { Shoot } \\
\text { length }\end{array}$ & $\begin{array}{l}\mathbf{N}^{\circ} \text { of } \\
\text { tillers per } \\
\text { plant }\end{array}$ & $\begin{array}{c}\text { Shoot } \\
\text { biomass }\end{array}$ & $\begin{array}{c}\text { Root } \\
\text { biomass }\end{array}$ \\
\hline Treatments & 11 & $48^{\mathrm{ns}}$ & $104^{* * *}$ & $29^{* * * *}$ & $22^{* * *}$ & $127^{* *}$ & $70^{* * *}$ & $466^{* * *}$ & $122^{* * *}$ \\
\hline Amendments (A) & 2 & $134^{* *}$ & $517^{* * *}$ & $145^{* * *}$ & $91^{* * *}$ & $196^{*}$ & $356^{* * *}$ & $178^{* * *}$ & $523^{* * *}$ \\
\hline Biopower (B) & 1 & $0.22^{\text {ns }}$ & $17 \mathrm{~ns}$ & $1.16^{\mathrm{ns}}$ & $0.58^{\mathrm{ns}}$ & $51^{\mathrm{ns}}$ & $1.78^{\mathrm{ns}}$ & $0.41^{\mathrm{ns}}$ & $2.26^{\mathrm{ns}}$ \\
\hline EM & 1 & $13^{\text {ns }}$ & $47^{* *}$ & $0.05^{\mathrm{ns}}$ & $1.14^{\mathrm{ns}}$ & $0.03^{\mathrm{ns}}$ & $0.00^{\mathrm{ns}}$ & $0.03^{\mathrm{ns}}$ & $0.04^{\mathrm{ns}}$ \\
\hline$A \times B$ & 2 & $4.4^{\mathrm{ns}}$ & $5.9^{\text {ns }}$ & $4.29^{\mathrm{ns}}$ & $20^{* * * *}$ & $61^{\mathrm{ns}}$ & $2.53^{\mathrm{ns}}$ & $1.79^{\mathrm{ns}}$ & $9.94^{\mathrm{ns}}$ \\
\hline $\mathrm{A} \times \mathrm{EM}$ & 2 & $12^{\text {ns }}$ & $8.7^{\mathrm{ns}}$ & $8.49^{\text {ns }}$ & $6.2^{*}$ & $179 *$ & $0.25^{\mathrm{ns}}$ & $2.67^{\mathrm{ns}}$ & $13.2^{\mathrm{ns}}$ \\
\hline $\mathrm{B} \times \mathrm{EM}$ & 1 & 28 & $0.25^{\mathrm{ns}}$ & $0.12^{\mathrm{ns}}$ & $0.02^{\mathrm{ns}}$ & $72^{\mathrm{ns}}$ & $16^{\mathrm{ns}}$ & $1.03^{\mathrm{ns}}$ & $88^{* *}$ \\
\hline $\mathrm{A} \times \mathrm{B} \times \mathrm{EM}$ & 2 & $93^{*}$ & $7.6^{\mathrm{ns}}$ & $2.8^{\mathrm{ns}}$ & $3.4^{\mathrm{ns}}$ & $199^{*}$ & $17^{\mathrm{ns}}$ & $0.89^{\text {ns }}$ & $81^{* * *}$ \\
\hline Error & 24 & 27 & 6.3 & 3.24 & 1.5 & 45 & 7.7 & 178 & 7.8 \\
\hline Total & 36 & & & & & & & & \\
\hline
\end{tabular}

$*, * *, * * *$ : significant at $\mathrm{P} \leq 0.05,0.01$, and 0.001 , respectively.

ns: non significant. 
Table 2. Effect of soil amendments, biopower, and EM application on various rice vegetative growth parameters after 90 , 120 , and 150 d growth stages.

\begin{tabular}{|c|c|c|c|c|c|c|c|c|c|c|c|c|}
\hline \multirow[b]{2}{*}{ Treatments } & \multicolumn{4}{|c|}{$90 \mathrm{~d}$ after sowing } & \multicolumn{4}{|c|}{$120 \mathrm{~d}$ after sowing } & \multicolumn{4}{|c|}{$150 \mathrm{~d}$ after sowing } \\
\hline & SL & TPP & SB & RB & SL & TPP & SB & RB & SL & TPP & SB & RB \\
\hline & $\mathrm{cm}$ & & $-\mathrm{g}-$ & $\overline{ }$ & $\mathrm{cm}$ & 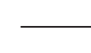 & $-\mathrm{g}-$ & $\overline{-}$ & $\mathrm{cm}$ & & $-\mathrm{g}$ & \\
\hline \multicolumn{13}{|l|}{$\begin{array}{l}\text { NPK } \\
\text { fertilizers }\end{array}$} \\
\hline Control & $57.0 \mathrm{a}-\mathrm{c}$ & $9 \mathrm{~cd}$ & $3.90 \mathrm{de}$ & $2.11 \mathrm{~d}$ & $91 \mathrm{a}-\mathrm{c}$ & $9 \mathrm{c}$ & $19.5 \mathrm{bc}$ & $4.4 \mathrm{~d}$ & $88 b-d$ & $11 \mathrm{c}$ & $17.4 \mathrm{~cd}$ & $6.7 \mathrm{c}$ \\
\hline $\mathrm{BP}$ & $50.2 \mathrm{c}$ & $10 \mathrm{c}$ & $2.87 \mathrm{de}$ & $4.96 b c$ & $84 b c$ & $9 \mathrm{c}$ & $16.0 \mathrm{c}$ & $5.3 \mathrm{~d}$ & $82 \mathrm{~cd}$ & $8 \mathrm{c}$ & $9.8 \mathrm{~d}$ & $5.7 \mathrm{c}$ \\
\hline EM & $51.5 \mathrm{bc}$ & $7 \mathrm{~cd}$ & $1.45 \mathrm{e}$ & $1.53 \mathrm{~d}$ & $82 \mathrm{c}$ & $10 \mathrm{c}$ & $19.0 \mathrm{bc}$ & $3.4 \mathrm{~d}$ & $79 d$ & $10 \mathrm{c}$ & $15.2 \mathrm{~cd}$ & $4.8 \mathrm{c}$ \\
\hline $\mathrm{BP}+\mathrm{EM}$ & $57.8 \mathrm{a}-\mathrm{c}$ & $5 d$ & $2.42 \mathrm{de}$ & $1.78 \mathrm{~d}$ & $100 \mathrm{a}$ & $9 \mathrm{c}$ & $22.2 \mathrm{bc}$ & $3.9 \mathrm{~d}$ & $84 \mathrm{~cd}$ & $10 \mathrm{c}$ & $14.9 \mathrm{~cd}$ & $11.4 \mathrm{c}$ \\
\hline \multicolumn{13}{|l|}{$\begin{array}{l}\text { Green } \\
\text { manure }\end{array}$} \\
\hline Control & $57 \mathrm{ac}$ & $10 \mathrm{c}$ & 3.0de & $1.81 \mathrm{~d}$ & $90 a-c$ & $10 \mathrm{c}$ & $18.7 \mathrm{bc}$ & $4.7 \mathrm{~d}$ & $88 \mathrm{bd}$ & $11 \mathrm{c}$ & $52.5 \mathrm{bc}$ & $7.5 \mathrm{c}$ \\
\hline $\mathrm{BP}$ & $55 \mathrm{ac}$ & $9 \mathrm{~cd}$ & $4.5 \mathrm{de}$ & $2.33 \mathrm{~d}$ & $96 a b$ & $10 \mathrm{c}$ & $21.5 \mathrm{bc}$ & $4.6 \mathrm{~d}$ & $100 \mathrm{a}$ & $12 \mathrm{c}$ & $60.3 b$ & $17.5 \mathrm{c}$ \\
\hline EM & $57 \mathrm{ac}$ & $9 \mathrm{~cd}$ & $5.7 \mathrm{bd}$ & $2.33 \mathrm{~d}$ & $96 a b$ & $7 \mathrm{c}$ & $19.2 \mathrm{bc}$ & $6.7 \mathrm{~cd}$ & $94 \mathrm{ac}$ & $11 \mathrm{c}$ & $59.3 \mathrm{bc}$ & $18.1 \mathrm{c}$ \\
\hline $\mathrm{BP}+\mathrm{EM}$ & $61 \mathrm{ab}$ & $9 \mathrm{~cd}$ & $5.5 \mathrm{~cd}$ & $3.25 \mathrm{~cd}$ & $100 \mathrm{a}$ & $10 \mathrm{c}$ & $24.3 b$ & $7.6 \mathrm{~cd}$ & $98 a b$ & $9 \mathrm{c}$ & $50.8 \mathrm{bd}$ & $12.0 \mathrm{c}$ \\
\hline \multicolumn{13}{|l|}{$\begin{array}{l}\text { Farmyard } \\
\text { manure }\end{array}$} \\
\hline Control & $60 \mathrm{ac}$ & $23 \mathrm{a}$ & $10.1 \mathrm{a}$ & $9.3 \mathrm{a}$ & $102 a$ & $20 a b$ & $47 \mathrm{a}$ & $23 \mathrm{a}$ & $89 b-d$ & $20 \mathrm{~b}$ & $125 \mathrm{a}$ & $48 b$ \\
\hline $\mathrm{BP}$ & $63 a$ & $19 a b$ & $8.9 \mathrm{ab}$ & $5.3 b c$ & $102 a$ & $18 a b$ & $46 a$ & $11 b c$ & $102 \mathrm{a}$ & $20 \mathrm{~b}$ & $141 \mathrm{a}$ & $45 b$ \\
\hline EM & $63 a$ & $19 \mathrm{ab}$ & $10.1 \mathrm{a}$ & $8.5 \mathrm{a}$ & $96 a b$ & $16 \mathrm{~b}$ & $44 a b$ & $13 b$ & $92 a-c$ & $24 \mathrm{a}$ & $156 a$ & $57 \mathrm{ab}$ \\
\hline $\mathrm{BP}+\mathrm{EM}$ & $58 \mathrm{a}-\mathrm{c}$ & $17 b$ & $8.2 \mathrm{a}-\mathrm{c}$ & $6.1 \mathrm{~b}$ & $90 a-c$ & $21 \mathrm{a}$ & $42 \mathrm{a}-\mathrm{c}$ & $19 a$ & $93 a-c$ & $25 \mathrm{a}$ & $159 a$ & $75 \mathrm{a}$ \\
\hline
\end{tabular}

Values with different letters in a column are significantly different according to Duncan's Multiple Range Test $(\mathrm{P} \leq 0.05)$.

SL: Shoot length; TPP: Tillers per plant; SB: Shoot biomass; RB: Root biomass; BP: Biopower; BP+EM: Biopower+EM; EM: effective microorganisms.

Table 3. ANOVA for the effect of soil amendments, biopower, and EM application on various rice vegetative and reproductive growth parameters at maturity (150 d after sowing).

\begin{tabular}{|c|c|c|c|c|c|c|c|}
\hline \multirow[b]{2}{*}{ Trait } & \multirow[b]{2}{*}{ df } & \multicolumn{6}{|c|}{ Mean squares } \\
\hline & & $\begin{array}{l}\text { Shoot } \\
\text { length }\end{array}$ & $\begin{array}{c}\mathrm{N}^{\circ} \text { of } \\
\text { tillers per } \\
\text { plant }\end{array}$ & $\begin{array}{c}\text { Shoot } \\
\text { biomass }\end{array}$ & $\begin{array}{c}\text { Root } \\
\text { biomass }\end{array}$ & $\begin{array}{l}\text { Grain } \\
\text { yield }\end{array}$ & $\begin{array}{c}\text { 100-grain } \\
\text { weight }\end{array}$ \\
\hline Treatments & 11 & $957^{* * *}$ & $92^{* * *}$ & $5596^{* * * *}$ & $836^{* * * *}$ & $105^{\text {*** }}$ & $0.050^{* * *}$ \\
\hline Amendments (A) & 2 & $734^{* * *}$ & $1426^{* * *}$ & $28921^{* * * *}$ & $5137^{* * * *}$ & $432^{* * *}$ & $0.158^{* * *}$ \\
\hline Biopower (B) & 1 & $174^{*}$ & $5.8^{\mathrm{ns}}$ & $16^{\mathrm{ns}}$ & $29^{\mathrm{ns}}$ & $12^{\text {ns }}$ & $0.024^{\mathrm{ns}}$ \\
\hline EM & 1 & 0.653 & $2.7^{\mathrm{ns}}$ & $118^{\mathrm{ns}}$ & $170^{*}$ & $13^{\mathrm{ns}}$ & $0.002^{\mathrm{ns}}$ \\
\hline$A \times B$ & 2 & $40^{\mathrm{ns}}$ & $0.93^{\mathrm{ns}}$ & $32^{\mathrm{ns}}$ & $3.3^{\mathrm{ns}}$ & $20^{\mathrm{ns}}$ & $0.035^{*}$ \\
\hline $\mathrm{A} \times \mathrm{EM}$ & 2 & $131 *$ & $2.8^{\mathrm{ns}}$ & $152^{\mathrm{ns}}$ & $91^{\mathrm{ns}}$ & $55^{* *}$ & $0.052^{* *}$ \\
\hline $\mathrm{B} \times \mathrm{EM}$ & 1 & $27^{\mathrm{ns}}$ & $3.3^{\mathrm{ns}}$ & $20^{\mathrm{ns}}$ & $87^{\mathrm{ns}}$ & $5^{\mathrm{ns}}$ & $0.004^{\mathrm{ns}}$ \\
\hline $\mathrm{A} \times \mathrm{B} \times \mathrm{EM}$ & 2 & $381^{* * * *}$ & $14.8^{\mathrm{ns}}$ & $83^{\text {ns }}$ & $183^{* *}$ & $57^{* *}$ & $0.002^{\mathrm{ns}}$ \\
\hline Error & 24 & 39 & 5.9 & 149 & 39 & 11 & 0.011 \\
\hline Total & 36 & & & & & & \\
\hline
\end{tabular}

${ }^{*},{ }^{* *},{ }^{* * *}$ significant at $\mathrm{P} \leq 0.05, \mathrm{P} \leq 0.01$, and $\mathrm{P} \leq 0.001$, respectively. ns: non significant.

the 90 and 120 d growth stages due to both biofertilizers, root biomass was enhanced by EM and EM + Biopower applied at the $150 \mathrm{~d}$ growth stage. Effect of combined inoculation of the two biofertilizers was much more evident than EM applied alone (Table 2).
Effect of biofertilizers and soil amendments on plant reproductive growth

ANOVA shows that the effect of soil amendment was significant for grain yield and 100-grain weight. In contrast, effects of EM and Biopower were not significant 
for both these reproductive growth parameters. Effect of $\mathrm{A} \times \mathrm{B}$ was significant for 100 -grain weight while $\mathrm{A} \times \mathrm{EM}$ was significant for both grain yield and 100-grain weight. Tripartite interaction of $\mathrm{A} \times \mathrm{B} \times \mathrm{EM}$ was significant for grain yield (Table 3 ).

Grain yield showed a variable response to Biopower and EM in different soil amendments. Applying Biopower in the NPK fertilizer amendment resulted in a 55\% reduction in grain yield. Conversely, in the green manure amendment, a significant $99 \%$ increase in grain yield was recorded by applying Biopower. The effect of applying Biopower in the farmyard manure amendment was not observable (Figure 1A). EM application enhanced grain yield by $46 \%$ in the green manure amendment. In contrast, there was a $24 \%$ reduction in grain yield by applying EM in farmyard manure. The effect of combining EM and Biopower was not significant in none of the three soil amendment systems (Fig. 1A). Earlier studies depicted variable effects of EM application on crop growth and
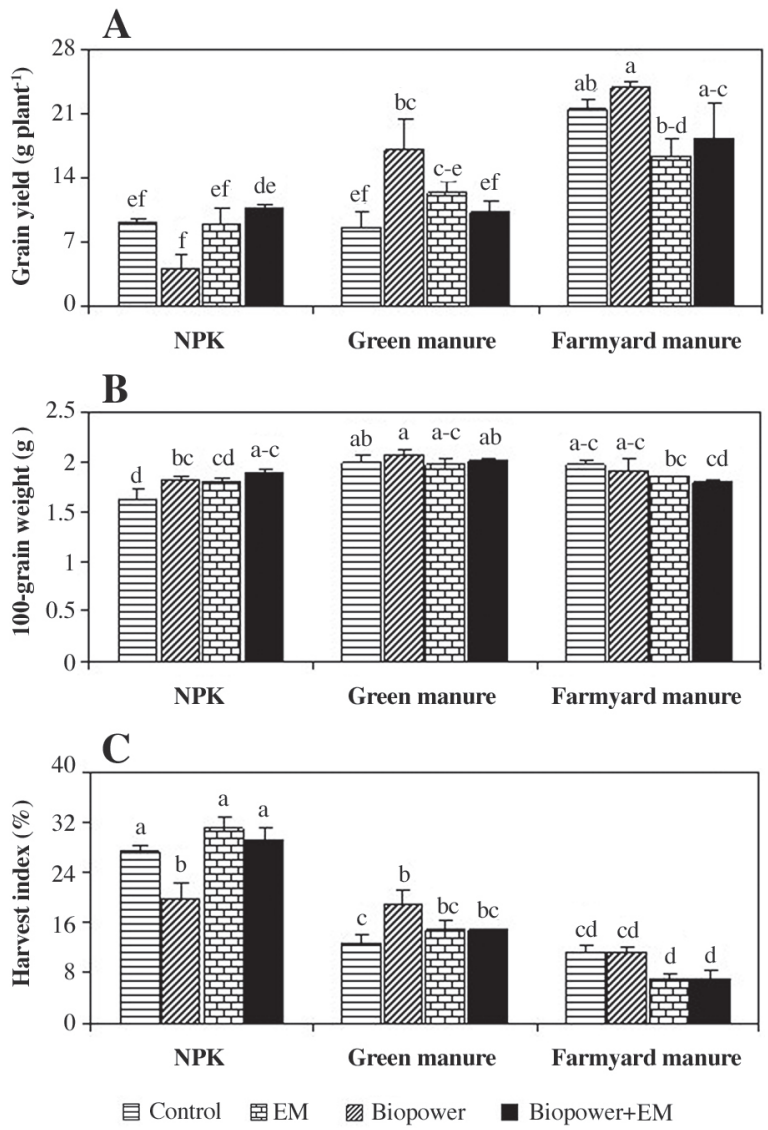

Values with different letters at the top of the bars are significantly different according to Duncan's Multiple Range Test $(\mathrm{P} \leq 0.05)$.

Figure 1. Effect of Biopower and EM application on rice grain yield, 100-grain weight, and harvest index in different soil amendment systems. Vertical bars show standard error of means of three replicates. yield; some researchers have shown positive effects of EM (Javaid, 2006; Khaliq et al., 2006; Javaid and Bajwa, 2010) while others reported negative or no effects (Bajwa et al., 1999; Formowitz et al., 2007; Daiss et al., 2008). According to Kinjo et al. (2000), the lack of consistency in experimental results when applying EM may be due to variable cultural conditions employed in previous studies. However, this study reveals that the effect of applying EM on crop growth and yield is associated with the type of soil amendment used.

Inoculation of EM and Biopower, either alone or combined, enhanced 100-grain weight in the NPK fertilizer amendment. The effect of Biopower and combined inoculation was significant. In contrast, applying biofertilizer to farmyard manure reduced 100 -grain weight. In green manure amended soil, the effect of either biofertilizer was not significant (Figure 1B). The effect of the two biofertilizers on the harvest index in different soil amendment systems was generally similar to effect on grain yield (Figure 1C).

\section{CONCLUSIONS}

This study concludes that the beneficial effects of EM and Biopower can best be exploited by using them combined with a suitable soil amendment. Both of these biofertilizers markedly enhanced rice shoot biomass and grain yield in the green manure amendment.

\section{ACKNOWLEDGEMENTS}

We express our sincere thanks to Prof. Dr. Tahir Hussain, Director of the Nature Farming Research Centre, Faisalabad for providing us with EM solution and to Dr. Fouzia Yousaf Hafeez, NIBGE Pakistan, for providing us with Biopower.

\section{RESUMEN}

Efecto de biofertilizantes combinado con enmiendas del suelo sobre plantas de arroz en macetas. El presente estudio en macetas fue realizado para investigar el efecto de la aplicación combinada de dos biofertilizantes comerciales, Biopower y EM (Effective Microorganisms), en el crecimiento y producción de arroz (Oryza sativa L.) en suelos enmendados con estiércol de granja, abono verde y fertilizantes NPK. Biopower es un producto del Nuclear Institute for Biotechnology and Genetic Engineering (NIBGE), Pakistán, que contiene especies de diazótrofos asociativos y endofíticos. Effective Microorganisms es un producto desarrollado por científicos japoneses que consiste en microorganismos benéficos co-existentes, principalmente especies de bacterias fotosintéticas y 
ácido lácticas, y levadura. La aplicación de Biopower afectó adversamente el crecimiento y producción vegetal en enmienda de fertilizante NPK. Inversamente, este biofertilizante mejoró marcadamente el crecimiento y producción vegetal en suelo enmendado con abono verde mientras en enmienda con estiércol de granja su efecto fue insignificante. En enmienda con estiércol verde, la aplicación de EM mejoró el rendimiento de grano en $46 \%$. Co-inoculación de Biopower y EM mejoró marcadamente el crecimiento radical y de brotes en suelo enmendado con estiércol de granja. El presente estudio concluye que los dos biofertilizantes mejoraron marcadamente la biomasa de brotes y rendimiento de grano en suelos enmendados con abono verde.

Palabras clave: fijadores de $\mathrm{N}_{2}$ asociados, Biopower, microorganismos efectivos, arroz, enmiendas de suelo.

\section{LITERATURE CITED}

Bajwa, R., A. Javaid, and N. Rabbani. 1999. EM and VAM technology in Pakistan. Effect of organic amendments and EM on VA mycorrhiza, nodulation and crop growth in Trifolium alexandrianum L. Pakistan Journal of Biology Sciences 2:590-593.

Daiss, N., M.G. Lobo, A.R. Socorro, U. Brückner, J. Heller, and M. Gonzalez. 2008. The effect of three organic pre-harvest treatments on Swiss chard (Beta vulgaris L. var. cycla L.) quality. European Food Research and Technology 226:345-353.

Daly, M.J., and D.P.C. Stewart. 1999. Influence of effective microorganisms (EM) on vegetative production and carbon mineralization - a preliminary investigation. Journal of Sustainable Agriculture 14:15-25.

Formowitz, B., F. Elango, S. Okumoto, T. Muller, and A. Buerkert. 2007. The role of effective microorganisms in the composting of banana (Musa ssp.) residues. Journal of Plant Nutrition and Soil Science 170:649656.

Higa, T. 1991. Effective microorganisms: A biotechnology for mankind. 8-14 p. In Parr, J.F., S.B. Hornick, and C.E. Whiteman (eds.) Proceedings of the First International Conference on Kyusei Nature Farming. U.S Department of Agriculture, Washington, D.C., USA.

Higa, T. 2000. What is EM technology? EM World Journal 1:1-6.

Hussain, T., A.D. Anjum, and J. Tahir. 2002. Technology of beneficial microorganisms. Nature Farming \& Environment 3:1-14.

Hussain, T., T. Javaid, J.F. Parr, G. Jilani, and M.A. Haq. 1999. Rice and wheat production in Pakistan with effective microorganisms. American Journal of Alternative Agriculture 14:30-36.
Irissarri, P., and B. Reinhold-Hurek. 2001. Azoarcus sp. strain BH72 as a model for nitrogen-fixing grass endophytes. Journal of Biotechnology 106:169-178.

IRRI. 1996. IRRI towards 2020. 43 p. International Rice Research Institute (IRRI), Los Baños, Laguna, Philippines.

James, E.K., G. Gyaneshwar, W.L. Barraquio, and J.K. Ladha. 1999. Endophytic diazotrophs associated with rice. In Ladha, J.K., and P.N. Reddy (eds.) The quest for nitrogen fixation in rice. International Rice Research Institute, Manila, Philippines.

Javaid, A. 2006. Foliar application of effective microorganisms on pea as an alternative fertilizer. Agronomy for Sustainable Development 26:257-262.

Javaid, A. 2009. Growth, nodulation and yield of black gram [Vigna mungo (L.) Hepper] as influenced by biofertilizers and soil amendments. African Journal of Biotechnology 8:5711-5717.

Javaid, A., and R. Bajwa. 2010. Field evaluation of effective microorganisms for improved growth and nutrition of Vigna radiata (L.) Wilczek. Turkish Journal of Agriculture and Forestry (In press), doi:10.3906/tar-1001-599.

Javaid, A., R. Bajwa, and T. Anjum. 2008. Effect of heat sterilization and EM (effective microorganisms) application of wheat (Triticum aestivum L.) grown in organic matter amended soils. Cereal Research Communications 36:489-499.

Javaid, A., and N. Mahmood. 2010. Growth and nodulation response of soybean to biofertilizers. Pakistan Journal of Botany 42:863-871.

Javaid, A., and M.B.M. Shah. 2010. Growth and yield response of wheat to EM (Effective microorganisms) and parthenium green manure. African Journal of Biotechnology 9:3378-3381.

Khaliq, A., M.K. Abbasi, and T. Hussain. 2006. Effect of integrated use of organic and inorganic nutrient sources with effective microorganisms (EM) on seed cotton yield in Pakistan. Bioresource Technology 97:967-972.

Kinjo, T., K. Pérez, E. de Almeida, M.A.G. Ramos, and J.O. de Oliveia. 2000. Plant growth affected by EMBokashi and chemical fertilizers. Nature Farming \& Environment 1:33-38.

Ladha, K., F.J. Bruijin, and K.A. Malik. 1997. Introduction: assessing opportunities for nitrogen fixation in rice - a frontier project. Plant and Soil 194:1-10.

Malik, K.A., B. Rakhshanda, S. Mehnaz, G. Rasul, M.S. Mirza, and S. Ali. 1997. Association of nitrogenfixing plant-growth-promoting rhizobacteria (PGPR) with kallar grass and rice. Plant and Soil 194:37-44. 
Raimam, M.P., U. Albino, M.F. Cruz, G.M. Lovato, F. Spago, T.P. Ferracin, et al. 2007. Interaction among free-living $\mathrm{N}$-fixing bacteria isolated from Drosera villosa var. villosa and AM fungi (Glomus clarum) in rice (Oryza sativa). Applied Soil Ecology 35:25-34.

Steel, R.G.D., and J.H. Torrie. 1980. Principles and procedures of statistics. McGraw Hill Book, New York, USA.

Yadav, S.P. 2002. Performance of effective microorganisms (EM) on growth and yields of selected vegetables. Nature Farming \& Environment 1:35-38.
Yan, P.S., and H.L. Xu. 2002. Influence of EM Bokashi on nodulation, physiological characters and yield of peanut in nature farming fields. Journal of Sustainable Agriculture 19:105-112.

Yanni, Y.G., R.Y. Rizk, V. Corich, A. Squartini, K. Ninke, S. Philip-Hollingsworth, et al. 1997. Natural endophytic associations between Rhizobium leguminosarum bv. trifolii and rice roots and assessment of its potential to promote rice growth. Plant and Soil 194:99-114. 